\title{
Who owns the robots rules the world
}

\section{Workers can benefit from technology that substitutes robots or other machines for their work by owning part of the capital that replaces them}

Keywords: robots, job displacement, lower pay, income inequality, employee ownership

\section{ELEVATOR PITCH}

Robots, that is any sort of machinery from computers to artificial intelligence programs that provides a good substitute for work currently performed by humans, can increasingly replace workers, even highly skilled professionals, and thus reduce opportunities for good jobs and pay. But, with appropriate policies, the higher productivity due to robots can improve worker well-being by raising incomes and creating greater leisure for workers. Consider the way Google reduces the need for reference librarians and research assistants, or the way massive open online courses reduce the need for professors and lecturers. How these new technologies affect worker wellbeing and inequality depends on who owns them.

\section{KEY FINDINGS}

\section{Pros}

๑ Policy can eliminate technology-induced joblessness.

- Labor can gain from labor-saving and capitalsaving technologies if its supply is less elastic than capital's.

- Skill-biased technical change could raise the relative demand for skilled workers faster than the supply of skilled workers increases.

$\oplus$ Workers can earn more of their income from capital than from working-by owning part of the robots that replace them.

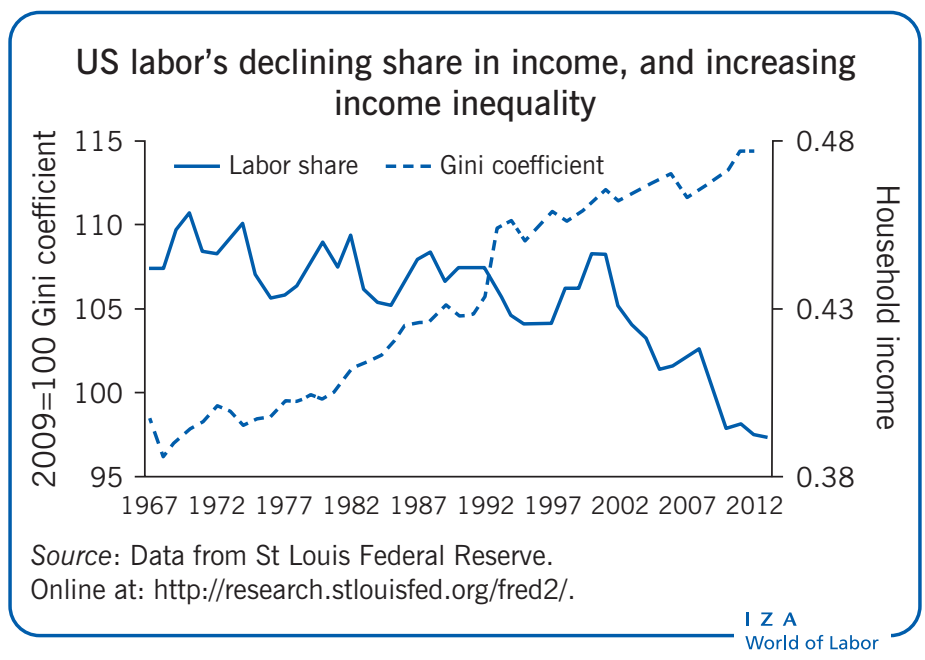

\section{Cons}

- Robots, software, and apps are replacing labor. Robots could take the good jobs at high pay and leave the low-pay jobs to humans.

- The distribution of income in advanced countries has shifted toward capital.

- The ownership of robots is the prime determinant of how they affect most workers.

\section{AUTHOR'S MAIN MESSAGE}

As companies substitute machines and computers for human activity, workers need to own part of the capital stock that substitutes for them to benefit from these new "robot" technologies. Workers could own shares of the firm, hold stock options, or be paid in part from the profits. Without ownership stakes, workers will become serfs working on behalf of the robots' overlords. Governments could tax the wealthy capital owners and redistribute income to workers, but that is not the direction societies are moving in. Workers need to own capital rather than rely on government income redistribution policies. 


\section{MOTIVATION}

What explains the high rate of joblessness, slow growth of real wages, and continued inequality in many advanced countries years after the Great Recession? Some analysts and headline writers believe that the development of robots and other machines with artificial intelligence explains much of the jobs problem (see Robot substitutes for human labor). Behind the headlines are advances in artificial intelligence that create machines that are far better substitutes for human intelligence than seemed possible just a few years ago: the Google driverless car; the chess-playing computer Deep Blue, beating Kasparov as world champion; Watson, the artificially intelligent computer system, becoming the greatest Jeopardy player; the Google search engine knowing more than any of us on every subject.

\section{Robot substitutes for human labor}

The term "robots" refers broadly to any sort of machinery, from computers to artificial intelligence programs, that provides a good substitute forwork currently performed by humans. This ranges from computers with artificial intelligence programs that bear no resemblance to humans, to robot vaccuum cleaners and Google cars, to social robots designed to look and act as if they are human. It does not matter whether a robot/machine has a humanoid appearance, as long as it can perform human functions. Advances in computer power and the development of artificial intelligence programs and wiring of microchips that can assess information and make decisions are rapidly improving the ability of machines to perform complicated tasks that seemed impossible just a decade or so ago. Taking the continuing progress in developing smarter technologies as a given, the focus here is on the social and economic issue of the ownership of these technologies.

\section{DISCUSSION OF PROS AND CONS}

The 2012 publication Race against the Machine makes the case that the digitalization of work activities is proceeding so rapidly as to cause dislocations in the job market beyond anything previously experienced [1]. Unlike past mechanization/automation, which affected lower-skill blue-collar and white-collar work, today's information technology affects workers high in the education and skill distribution. Machines can substitute for brains as well as brawn. On one estimate, about $47 \%$ of total US employment is at risk of computerization [2].

If you doubt whether a robot or some other machine equipped with digital intelligence connected to the internet could outdo you or me in our work in the foreseeable future, consider news reports about an IBM program to "create" new food dishes (chefs beware), the battle between anesthesiologists and computer programs/robots that do their job much cheaper, and the coming version of Watson ("twice as powerful as the original") based on computers connected over the internet via IBM's Cloud [3]. On the darker side, you do not have to be paranoid to be paranoid about the potential technologies that the super-secret computers of the US National Security Agency (NSA) have on their digital drawing-boards.

Dr Who, on behalf of humanity, please give up acting on the 50th anniversary BBC show! Come back to the real world and stop the NSA's Daleks and Cybermen before it is too late!

While concern about the economics of computerization is widespread, many observers view the notion that robots destroy jobs as misguided technocratic thinking, science-fiction fantasy, or neo-Luddite nonsense. Fears of machines creating mass unemployment arose 
during some past periods of extended joblessness and were proved false as the economy recovered full employment. In the Great Depression, US President Franklin D. Roosevelt blamed unemployment on his country's failure to employ the surplus labor created by the efficiency of its industrial processes [3], while the technocracy movement sought to resolve the problem by replacing markets with planning by engineers. In the early 1960s, widespread fears that automation was eliminating thousands of jobs per week led the Kennedy and Johnson administrations to examine the link between productivity growth and employment. In the 1990s, Jeremy Rifkin predicted that technology would produce the "End of Work"-just before the dot.com boom raised the ratio of employees to the adult population in the US to an alltime peak [4].

\section{What happens to employment and leisure?}

Mainstream economists' traditional response to the fear of automation and robots is the professional version of Alfred E. Neuman's "What, me worry?" response to life: "The market will take care of everything." If the new technologies create some joblessness, a bit of expansionary macro fiscal and monetary policy will guarantee sufficient demand to restore full employment. If, in the distant future, people are satiated with consumption goods and services, the economist's answer is also reassuring: People will simply reduce their hours at work and allocate more time to leisure, as Keynes predicted in his 1930 article on "Economic Possibilities for Our Grandchildren" [5].

How will we spend our leisure in this ideal state? Perhaps as we increasingly do now-playing computer games and watching videos. If the computer stomping us in digital war or sports contests discourages us from becoming gamers, or ifTV soap operas get boring, we can try the kinds of activity that Keynes presumably envisaged: lawn tennis or cricket, tea in the garden, admiring great art or symphonic music.

Economics holds that comparative advantage rather than absolute advantage determines trade. By extension, even if robots and other machines dominate humans at all jobs, comparative advantage guarantees that we will find work at the activities where the relative advantage of machines is least. If you understand comparative advantage but still fear robots turning you jobless, technophiles of innovation will denounce you as a neo-Luddite alarmist, a socialist, or a sociologist-or something worse.

\section{What happens to wages and incomes?}

Employment, however, is just one side of the labor market calculus. What happens to wages is also important to well-being. If robots take the good jobs at high pay and humans get the low-pay leftovers, the living standards of persons dependent on labor income will fall. In such a scenario, Luddite fears would appear more realistic than assurances that comparative advantage guarantees work for all in a well-functioning economy.

But economics has a response to this danger. Herbert Simon's 1965 analysis of technological change showed that, in a well-functioning market economy, labor gains from labor-saving and capital-saving technologies-as long as the labor supply curve is less elastic than the capital supply curve [6]. In a full-employment economy, any technological advance raises the pay for the input with inelastic supply relative to the input with elastic supply. By treating capital as elastic and labor as inelastic, Simon essentially put Malthus upside down. 
The historical facts fit Simon's model. On the price side, the real return to capital has been roughly constant in the long run, which implies an infinitely elastic supply curve, while real wages have trended upward. On the quantity side, the stock of physical capital and the stock of knowledge capital have increased massively relative to labor. The world population has grown but birth rates have plummeted as societies have become richer, suggesting that population growth will continue to fall far short of the growth of knowledge and capital. But Simon treated labor as homogeneous, and ignored the distribution of ownership of robots and related machines that is central to analyzing the impact of robots/mechanization on society.

\section{Treating labor as heterogeneous under skill-biased technical change}

Labor economists treat labor as heterogeneous by making wage differences between skilled or educated workers and less skilled/less educated workers a prime area of research. Some analysts examine the job tasks and specific skills used in different occupations. As skill differentials increased over the past 40 years, despite a huge shift in the workforce toward skilled labor, many analysts have sought to explain the pattern of change in terms of skill-biased technical change that raised relative demand for skilled workers faster than the increasing supply of skilled workers. As we lack independent measures of the bias of technological change, it is hard to "prove" that technology does what the models claim it does. In almost all studies, technological change is an unmeasured factor operating behind the scenes.

The skill-biased story can explain some of the main facts, which is why economists devised it, although it does not fit all of the data [7]. And there is evidence that factors beyond technology-such as trade and immigration from low-wage, highly populous countries to advanced countries, and the weakening of trade unions throughout the advanced world-have also contributed to increased skill differentials and inequality. Since all advanced countries have access to the same technologies and have increased their supply of highly educated and skilled workers, moreover, the skill-bias hypothesis offers little insight into the different levels of inequality among countries. Inequality is higher in countries like the US, where labor market institutions such as trade unions and welfare state protections for workers are weak, than in countries where those institutions are stronger, as they are in many European countries.

The skill biased technology hypothesis captures part of reality but falls far short of a complete explanation of rising skill differentials and inequality, much less of changes in employment and unemployment over time and among countries. Moreover, to the extent that robotization has begun to extend up the skill ladder, with robots able to substitute for professionals as well as other workers, the bias of labor-saving technology will change. It is perhaps telling that the box of headlines on job-replacing robots shows no particular bias by level of skill. Whenever any task becomes cheaper to do with a machine than a person, eventually that task will shift to the machine unless humans take pay cuts. The "iron law" of the effect of robots on pay is that increased substitutability with human skills puts downward pressure on the wages of persons doing competing tasks-a pressure likely to grow in the future as technology improves the competence of robots and lowers their cost.

\section{Inequality in income and in capital}

If "robots" are capital equipment that embodies modern technology, the distribution of income in virtually all advanced countries has shifted toward robots/capital and against labor 
for the past two decades. From 1990 to 2009 the share of national income in wages, salaries, and benefits declined in 26 of 30 OECD countries, including all of the large economies-those of the US, Germany, Japan, the UK, and France [8]. Labor's share of national income declines when productivity increases faster than real wages.

\section{Robots vs workers: Recent headlines from news articles on robots and work}

- Dorrier, J. "Burger robot poised to disrupt fast food industry." SingularityHUB, August 8 , 2014.

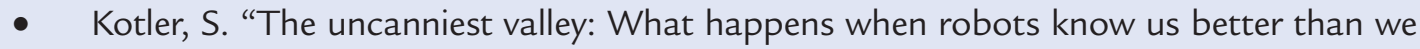
know ourselves." Forbes, July 20, 2014.

- Meltzer, T. "Robot doctors, online lawyers and automated architects: The future of the professions?" The Guardian, June 15, 2014.

- $\quad$ North, A. "Our robot nightmares." New York Times Op-Talk, June 29, 2014.

- Lewis, C. "GoCart robot delivers food in elderly and health care facilities." RobotEnomics, September 1, 2014.

- $\quad$ O'Toole, J. "Robots will replace fast-food workers." CNN Money, September 4, 2014.

- Jordan, B. "Chinese test self-printing robots." Fox News, March 4, 2014.

- "DR Congo recruits robots as traffic police." Al Jazeera, March 20, 2014.

- Gaudin, S. "Robots are taking mid-level jobs, changing the economy." ComputerWorld, October 31, 2011.

- Peplow, M. "Organic synthesis: The robo-chemist." Nature 512 (2014): 20-22.

- Klein, E. "How robots will replace doctors." The Washington Post, October 1, 2011.

- $\quad$ Aquino, J. "Nine jobs that humans may lose to robots." NBC News.com, 2012.

- "One in three jobs will be taken by software or robots by 2025." Slashdot, October 6, 2014.

- Worstall, T. "Phew, the robots are only going to take 45 percent of all the jobs." Forbes, September 18, 2013.

- Miller, C. "As robots grow smarter, American workers struggle to keep up." New York Times: The Upshot, December 15, 2014.

- $\quad$ Szondy, D. “Lowe's trials robot sales assistants." Gizmag, November 4, 2014.

- Niiler, E. "HERB: A robot that can unload a dishwasher and (sometimes) take apart an Oreo." The Washington Post, September 15, 2014.

- $\quad$ Eyre, M. “'Boris' the robot can load up dishwasher.” BBC News, September 14, 2014.

- Flowers, A. "If a computer can diagnose cancer, will doctors become obsolete?" FiveThirtyEight, August 22, 2014.

- $\quad$ Dorrier, J. "Robots able to pick peppers, test soil, and prune plants aim to replace farm workers." SingularityHUB, November 8, 2014. 
The magnitude of the declines varies: with the way national surveys measure wages, prices, gross domestic product (GDP), and employment; with the proportion of the workforce that is self-employed; with the difficulty of measuring labor and capital inputs; and with the proportion in the public sector, where productivity is hard to measure. In the US, labor's share, as estimated by the Bureau of Labor Statistics, fell more than labor's share as estimated by the Department of Commerce, and both differ from the OECD's estimates of the decline in labor's share. In developing countries, where many workers are in the informal sector, measurement difficulties are greater than in the advanced countries, but the share of national income going to labor seems also to have fallen, with a huge drop in China during its period of rapid growth. Given that capital income is distributed more unequally than labor income, the increased share of national product going to capital acts to raise income inequality in all countries.

Labor market analysis of inequality focuses, as noted, on incomes from labor. But here, too, capital is a substantial contributor to inequality. It is a substantial contributor to inequality in labor incomes because highly paid chief executive officers (CEOs) and top executives are paid stock options, restricted stock grants, and bonuses tied to capital income. While mode of pay does not tell the whole story (CEO-dominated boards could raise salaries if they were unable to pay executives through shares), it is telling that the persons with the greatest power in corporations prefer to be paid as owners rather than as wage and salary workers.

How should the increase in income inequality be assessed? Ages ago, when taxes on individuals and corporations were high and the distribution of wages relatively compressed in most advanced countries, the notion that greater inequality might spark innovation and economic growth had some plausibility. Some inequality is a necessary incentive to induce people to work harder. Narrowing the distribution of income and taxing businesses that make large profits through innovation reduces the incentive for entrepreneurship that is one of the virtues of capitalism. But today, after three decades or so of income redistribution from the middle class to the super-wealthy, that sort of argument has little traction. Organizations that favored labor market reforms that increased inequality, such as the OECD, now worry that "greater inequality in the distribution of market income...might endanger social cohesion" [8]. Others worry about the well-being of low-income citizens and their children as real wages and incomes fall. If the trend toward greater inequality continues, our societies will turn into a modern form of feudalism, with a few billionaires and their ilk dominating economic markets and governments as well, just as the lords and ladies of medieval Europe dominated their societies. The founders of the US believed that democracy could not survive with such high levels of inequality.

\section{Ownership is the key determinant of the impact of robots on workers}

The "who-owns-the-robots-rules-the-world" thesis is simple: Regardless of whether technological advance is labor-saving or capital-saving, skill-biased or not, and regardless of the speed with which robots or other machines approach or exceed human skill sets, the key to the effect of the new technologies on the well-being of people around the world is who owns the technologies.

A thought experiment readily captures the importance of ownership on effect. Consider a world in which we create robots/machines that are sufficiently good at mimicking our work activities that they could readily replace us and earn what we currently earn. Would this technology make us better off, or worse off? 
If we owned our replacements, we would have our current earnings and our time freed from labor to spend as we wished-playing computer games, drinking tea in the garden, engaging in wild orgies, or seeking other productive activity, possibly at lower wages. We would be better off.

If other persons owned our replacement robots, we would be jobless and searching for new work at lower pay while the owners of the robots would reap the pay/marginal product from the machines that took our jobs. The distribution of income would shift from us toward the owners of capital. They would be better off. We would be worse off.

\section{Replacement robots far-fetched?}

In the academic world the replacement robots are in clear sight. They go under the name of Massive Open Online Courses (MOOCs), which allow students anywhere in the world to download lectures produced by video experts, with access to chat rooms for discussions. Many colleges and universities credit students for taking MOOCs just as they do for taking live lectures. MOOC videos can feature famous professors at leading universities, regular faculty at any college or university, or whoever or whatever can produce a course that teaches students the relevant knowledge and skills. Because videos have effectively zero marginal cost to replicate, they are far less expensive than hiring full-time faculty to lecture students on the same material semester after semester.

Now imagine that you are one of the faculty who currently gives lectures as part of your job. Each semester you explain multivariate calculus and complex numbers using a blackboard and chalk. Suddenly your university announces that they have found the "killer MOOC video" for calculus and complex numbers, and give you your walking papers. Students around the world would much prefer to have the Rapping Mathster on the MOOC video teach them calculus and complex numbers than some babbling professor.

Perhaps you will find work as a temporary offline adjunct faculty, running sections and grading exams at reduced pay. Perhaps you will curse the MOOC video and leave academia (and maybe end up on Wall Street, where you can help other displaced quants destroy the world's financial system for the second time). Only if you had property rights over using the new technology in your course or shares in the firm that made the video would you directly benefit from MOOC technology. Who owns the property rights to the videos/robots rules the higher education world.

\section{Solution?}

What, then, is the solution to the declining economic position of labor in relation to capital, and the increased ability of robots and related technology to substitute for workers on many tasks?

One possibility is that trade unions could raise wages through collective bargaining and gain for workers a share of the higher productivity. That is the way workers have historically sought to increase their wages when firms have done better. But throughout the advanced world the influence of trade unions has weakened, becoming near to irrelevant in the private sector in some countries, such as the US.

Another possibility is that governments could use tax-and-spend policies to redistribute income toward lower-income citizens. That is the way welfare states have historically shifted income 
distributions from high-income to low-income citizens. But throughout the advanced world budgetary constraints and aging populations limit what most can do on the welfare side. In countries facing financial problems, the Troika-the International Monetary Fund (IMF), the European Commission, and the European Union (EU) Central Bank-have endorsed austerity programs that require countries to adopt policies that weaken trade unions, and reduce the pay and social benefits of ordinary workers. To be sure, social and political forces can change sharply in short periods of time. Big changes almost always come in short, sharp spurts. But it is difficult to see a burst of union activism and government programs changing the distribution of income toward labor in a future when robots are increasingly able to substitute for humans at workplaces.

Robots of the world unite? Maybe, but that may not benefit those of us who are flesh and blood instead of metal and circuits.

There is only one solution to the long-term challenge posed by machines substituting for human skills and reducing demand for skilled labor. That is for you, me, all of us to have a substantial ownership stake in the robot machines that will compete with us for our jobs and be the vehicle for capital's share of production. We must earn a substantial part of our incomes from capital ownership rather than from working. Unless workers earn income from capital as well as from labor, the trend toward a more unequal income distribution is likely to continue, and the world will increasingly turn into a new form of economic feudalism. We have to widen the ownership of business capital if we hope to prevent such a polarization of our economies.

There are diverse pathways to spread the ownership of capital. Ownership can take the form of worker assets in private pension funds or other collective savings vehicles that invest in shares on the stock market or that invest directly in equity in other firms. It can also take the form of workers buying shares or putting money in mutual funds themselves. But the form of ownership that potentially has the greatest economic benefit in dealing with robotization and the falling share of labor income is employee ownership.

Employee ownership refers to the many mechanisms for workers to gain an ownership stake in their firm: through owning shares held by an employee ownership trust; through receiving stock options as part of their pay; through having part of their pay come in the form of profitsharing or other forms of group incentive pay; through being able to buy shares at low prices via employee stock purchase plans.

Firms with compensation policies that give workers some capital stake in their firm have better average performance than others. They do this by inducing workers to work harder and smarter [9]. Exemplar firms throughout the world operate in these ways: John Lewis in the UK, Mondragon in Spain, and Google and most of the high-tech firms in the US.

\section{LIMITATIONS AND GAPS}

Because there are no independent measures of technological change, proving that technology does what models claim that it does is difficult. A skill-biased model can explain some of the facts but does not fit all the data. And factors beyond skills also contribute increased skill differentials and technology.

Labor market analysis of inequality focuses on incomes from labor, but capital is a substantial contributor to inequality. 


\section{SUMMARY AND POLICY ADVICE}

Stipulate that the main claims of this paper are correct: that the upward trend in capital's share and rising inequality combined with advances in artificial intelligence and robotization are moving our societies toward a 21st-century economic feudalism in which the owners of capital dominate the economy, and society more broadly. The problem in such a world is not workers losing jobs to machines. As long as the relative advantage of machines varies, there will be work for humans. The problem is that the owners of the machines will receive the vast bulk of the benefits of the technological progress. Whether such inequality will threaten social disorder, as the OECD and many other groups fear that current inequalities may do, or whether people will accept the new feudal order, is still unknown. But a world of massive inequality is surely not the most desirable outcome from technological change that can make everyone better off.

The best solution to this problem is for workers to own large shares of capital. How can citizens press policymakers to help spread employee ownership more widely? The US introduced tax benefits for Employee Stock Ownership Plans (ESOPs) in 1974, which helped spur a large ESOP sector that employs about 11 million workers today. The EU has endorsed such schemes in its various Pepper Reports and encouraged these forms of organization, though with, at best, modest success [10]. France mandated profit-sharing in the 1960s under de Gaulle. Tory and Labour governments in the UK have encouraged employment share purchase schemes. Many countries give tax breaks to employee stock purchase plans. But even without such breaks, enough firms in the US have extended some form of ownership stake to their workers that on the order of half of American employees get some part of their pay through profit-sharing, options, or stock ownership. In the US, at least, people with widely different ideological and economic views find attractive the notion of spreading ownership. One can imagine governments giving preferential treatment in procurement to firms that meet some basic "employee ownership" financial standard.

Given the different histories and economic structures of the advanced capitalist countries, each country will have to choose the way that best fits it to spread worker ownership of capital so as to give a stream of earnings from the technologies changing the world of work. If we don't succeed in spreading the ownership of capital more widely, many of us will become serfs working on behalf of the owners. Who owns the robots rules the world! Let us own the robots.

\section{Acknowledgments}

The author thanks an anonymous referee and the IZA World of Labor editors for many helpful suggestions on earlier drafts.

\section{Competing interests}

The IZA World of Labor project is committed to the IZA Guiding Principles of Research Integrity. The author declares to have observed these principles.

(c) Richard Freeman 


\section{REFERENCES}

\section{Further reading}

Atkinson, R. "Robots taking all our jobs? Ridiculous." InformationWeek, September 26, 2013. Online at: http://www.informationweek.com/global-cio/interviews/robots-taking-all-our-jobsridiculous $/ 240161845$

Snyder, M. "Robots and computers could take half our jobs within the next 20 years." The Economic Collapse, September 30, 2013. Online at: http://theeconomiccollapseblog.com/archives/oxfordprofessors-nearly-half-our-jobs-could-be-automated-within-the-next-20-years

\section{Key references}

[1] Brynjolfsson, E., and D. McAfee. Race against the Machine: How the Digital Revolution is Accelerating Innovation, Driving Productivity, and Irreversibly Transforming Employment and the Economy. Lexington, MA: Digital Frontier Press, 2012.

[2] Frey, C. B., and M. A. Osborne. The Future of Employment: How Susceptible are Jobs to Computerisation? Oxford Martin School Working Paper, September 17, 2013. Online at: http:// www.oxfordmartin.ox.ac.uk/downloads/academic/The_Future_of_Employment.pdf

[3] Hardy, Q. "IBM to announce more powerful Watson via the internet." New York Times, November 13, 2013. Online at: http://www.nytimes.com/2013/11/14/technology/ibm-toannounce-more-powerful-watson-via-the-internet.html?_r=0\&pagewanted=print

[4] Rifkin, J. The End of Work: The Decline of the Global Labor Force and the Dawn of the Post-Market Era. Kirkwood, NY: Putnam Publishing Group, 1995.

[5] Pecchi, L., and G. Piga (eds). Revisiting Keynes: Economic Possibilities for our Grandchildren. Cambridge, MA: MIT Press, 2008.

[6] Simon, H. A. The Shape of Automation (for Men and Management). New York: Harper and Row, 1965.

[7] Mishel, L., J. Schmitt, and H. Shierholz. Robots: Assessing the Job Polarization Explanation of Growing Wage Inequality. Economic Policy Institute Working Paper No. 295, January 11, 2013. Online at: http://www.epi.org/publication/wp295-assessing-job-polarization-explanation-wage-inequality

[8] OECD. OECD Employment Outlook 2012. Paris: OECD, 2012.

[9] Blasi, J. R., R. B. Freeman, and D. L. Kruse. The Citizen's Share: Putting Ownership Back in Democracy. New Haven, CT: Yale University Press, 2013.

[10] Lowitzsch, J., I. Hashi, and R. Woodward. The PEPPER IV Report: Benchmarking of Employee Participation in Profits and Enterprise Results in the Member and Candidate Countries of the European Union. Berlin: Inter-University Centre at the Institute for Eastern European Studies, Free University of Berlin, 2009. Online at: http://www.efesonline.org/LIBRARY/2009/PEPPER\%20 IV\%20Web\%200ct-09.pdf

The full reference list for this article is available from the IZA World of Labor website (http://wol.iza.org/articles/who-owns-the-robots-rules-the-world). 